\title{
Meningkatkan Hasil Belajar Siswa Materi Energi dan Pengaruhnya Dalam Kehidupan Melalui Penerapan Model Pembelajaran Kooperatif Tipe Student Teams Achievement Division (STAD) di Kelas III SDN 1 Mosiku Kabupaten Kolaka Utara
}

\author{
Semramma Patollong ${ }^{1, a)}$, Dorce Banne Pabunga ${ }^{2}$ \\ ${ }^{1}$ Alumni Jurusan Pendidikan Guru Sekolah Dasar, FKIP Universitas Halu Oleo, \\ J1. H.E.A. Mokodompit Kendari 93232, Indonesia \\ ${ }^{2}$ Dosen FKIP Universitas Halu Oleo, Jl. H.E.A. Mokodompit Kendari 93232, \\ Indonesia \\ a)e-mail: semrammapatollong.skgj@ gmail.com
}

\begin{abstract}
ABSTRAK
Tujuan penelitian adalah untuk meningkatkan hasil belajar siswa pada materi Energi dan Pengaruhnya Dalam Kehidupan melalui penerapan model pembelajaran kooperatif tipe Student Teams Achievement Division (STAD) di Kelas III SDN 1 Mosiku. Jenis penelitian ini adalah penelitian tindakan kelas, terdiri dari dua siklus. Prosedur penelitian meliputi: perencanaan, pelaksanaan tindakan, observasi dan evaluasi, dan refleksi. Teknik pengumpulan data dalam penelitian ini menggunakan hasil observasi dan evaluasi tes siklus. Hasil analisis penelitian menunjukkan bahwa aktivitas mengajar guru siklus I mencapai $85 \%$, aktivitas belajar siswa siklus I mencapai $75 \%$ dan hasil belajar siswa siklus I mencapai ketuntasan sebesar 60,7\% dengan nilai rata-rata mencapai 67,5. Aktivitas mengajar guru siklus II mencapai 90\%. Aktivitas belajar siswa siklus II mencapai $85 \%$. Hasil belajar siswa siklus II mencapai ketuntasan $89,3 \%$ dengan nilai rata-rata 76,8. Disimpulkan bahwa penerapan model pembelajaran kooperatif tipe STAD dapat meningkatkan hasil belajar siswa materi Energi dan Pengaruhnya Dalam Kehidupan di kelas III SDN 1 Mosiku Kabupaten Kolaka Utara.
\end{abstract}

Kata kunci: Model pembelajaran, Student Teams Achievement Division, hasil belajar, IPA

\begin{abstract}
The purpose of the study was to improve student learning outcomes in the material of Energy and Its Effects in Life through the application of cooperative learning models of the Student Teams Achievement Division (STAD) type in Class III SDN 1 Mosiku. This type of research is classroom action research, consisting of two cycles. Research procedures include: planning, action, observation and evaluation, and reflection. Data collection techniques in this study use the results of observations and cycle test evaluations. The results of the analysis of the study showed that the teacher's teaching activities in the first cycle reached $85 \%$, the students 'learning activities in the first cycle reached $75 \%$ and the students' learning outcomes in the first cycle reached $60.7 \%$ with an average score of 67.5 . The teacher's teaching activity in cycle II reaches $90 \%$. Student learning activities in cycle II reach $85 \%$. Student learning outcomes of cycle II reached $89.3 \%$ completeness with an average value of 76.8. It was concluded that the application of STAD type cooperative learning model can improve student learning outcomes in Energy material and its influence in life in class III SDN 1 Mosiku, North Kolaka Regency.
\end{abstract}

Keyword: : Learning Model, Student Teams Achievement Division, Learning Outcomes, Science 
secara aktif setiap guru dituntut untuk membuat desain pembelajaran yang tepat dan sesuai dengan materi yang diajarkan. Banyak model pembelajaran dan metode serta pendekatan pembelajaran yang dapat diterapkan. Namun, terkadang guru kurang menyadari perlunya variasi dalam pembelajaran agar siswa termotivasi dan aktif untuk belajar. Guru seringkali merasa sudah maksimal dalam pembelajaran. Kenyataannya setelah dilakukan refleksi hasil tes formatif yang merupakan gambaran daya serap siswa terhadap setiap pokok bahasan yang sudah diajarkan oleh guru justru bertolakbelakang. Pada saat itulah guru menyadari bahwa ternyata pembelajaran yang dilakukan selama ini belum sesuai dengan yang diharapkan.

Kondisi seperti inilah yang terjadi dalam suatu diskusi bersama teman sejawat (guru) di SDN 1 Mosiku ketika kami melakukan refleksi untuk mengkaji pentingnya peningkatan hasil belajar IPA siswa dalam upaya perbaikan pembelajaran dan pemecahan masalah belajar siswa di sekolah. Masalah yang yang muncul adalah guru merasa kesulitan mengajarkan materi Energi dan Pengaruhnya Dalam Kehidupan pada siswa, dan siswapun merasa sulit untuk memahami materi pelajaran tersebut yang ditunjukkan dengan rendahnya hasil belajar mereka pada materi pokok tersebut.

Hasil belajar siswa materi Energi dan Pengaruhnya Dalam Kehidupan selama dua tahun terakhir berada di bawah standar Kriteria Ketuntasan Minimal (KKM) yang ditetapkan di sekolah yaitu minimal $76 \%$ siswa memperoleh nilai 65. Pada semester genap tahun ajaran 2015/2016 ketuntasan hasil belajar siswa hanya mencapai $61,9 \%$, dari 21 siswa hanya 13 orang siswa $(61,9 \%)$ yang telah mencapai Kriteria Ketuntasan Minimal (KKM) yang ditetapkan sekolah sedangkan 8 orang siswa lainnya $(38,1 \%)$ tidak mencapai KKM. Karena itu, pembelajaran IPA di Kelas III SDN 1 Mosiku menunjukkan hasil yang belum optimal dan perlu diperbaiki untuk meningkatkan hasil belajar IPA siswa Kelas III SDN 1 Mosiku sesuai target ketuntasan penguasaan materi berdasarkan KKM.

Data hasil belajar di atas juga didukung oleh adanya catatan harian yang ada bahwa ternyata pada setiap kali pembelajaran berlangsung khususnya mata pelajaran IPA sangat sedikit siswa di Kelas III SDN 1 Mosiku yang aktif selama pembelajaran. Selama pembelajaran berlangsung siswa jarang mengajukan pertanyaan atau memberikan tanggapan terhadap penjelasan guru. Berdasarkan hal tersebut melalui diskusi dengan guru Kelas III yang merupakan teman sejawat, teridentifikasi beberapa kekurangan yang terjadi dalam pembelajaran. Siswa kurang aktif selama pembelajaran berlangsung, siswa kurang memperhatikan materi yang diajarkan guru sehingga pemahaman dan penguasan siswa terhadap materi pelajaran juga kurang. Sedangkan guru menyajikan materi pelajaran hanya dengan penjelasan yang bersifat informatif dan monoton yang menekankan pada belajar produk dan hafalan, kurang menarik dan tidak melibatkan siswa dalam kegiatan belajar interaktif untuk menemukan sendiri pemahaman yang bermakna serta mengembangkan keterampilan dan sikap/nilai yang bermanfaat dalam kehidupan sehari-hari.

Untuk memecahkan masalah tersebut, melalui diskusi dengan teman sejawat (guru) di SDN 1 Mosiku akhirnya dipilih/ditetapkan Model Pembelajaran Kooperatif Tipe Student Teams Achievement Devisions (STAD) sebagai alternatif tindakan untuk memperbaiki pembelajaran dan meningkatkan hasil belajar IPA pada siswa Kelas III SDN 1 Mosiku khususnya pada materi Energi dan Pengaruhnya Dalam Kehidupan.

Penerapan Model Pembelajaran Kooperatif Tipe STAD dalam kegiatan pembelajaran bidang studi secara umum mengacu pada konsep Slavin (2005:143) yang meliputi 5 (lima) langkah utama, yaitu: 1) penyajian materi; 2) kegiatan kelompok; 3) tes/evaluasi; 4) perhitungan skor perkembangan individu; dan 5) pemberian penghargaan kelompok. Langkah-langkah tersebut telah dikembangkan menjadi 6 (enam) langkah atau fase dalam pembelajaran kooperatif tipe STAD, yaitu: 1) menyampaikan tujuan dan memotivasi siswa; 2) menyajikan informasi/penyajian materi; 3) mengorganisasi siswa ke dalam kelompok-kelompok belajar; 4) membimbing siswa bekerja/belajar kelompok; 5) melakukan evaluasi dan penilaian baik secara individu maupun kelompok; dan 6) memberikan penghargaan kepada siswa secara kelompok. 
Penelitian yang dilakukan oleh Kolewora (2010) telah melakukan penelitian pada siswa Kelas V SDN 1 Kabangka Kabupaten Muna, menyimpulkan bahwa penerapan Model Pembelajaran Kooperatif Tipe STAD dapat meningkatkan hasil belajar siswa mata pelajaran IPA pada materi pokok alat indra manusia.

Masalah dalam penelitian adalah apakah penerapan model pembelajaran kooperatif tipe Student Teams Achievement Division (STAD) dapat meningkatkan hasil belajar siswa pada materi Energi dan Pengaruhnya Dalam Kehidupan di Kelas III SDN 1 Mosiku Kabupaten Kolaka Utara?. Tujuan penelitian adalah untuk meningkatkan hasil belajar siswa pada materi Energi dan Pengaruhnya Dalam Kehidupan melalui penerapan model pembelajaran kooperatif tipe Student Teams Achievement Division (STAD) di Kelas III SDN 1 Mosiku Kabupaten Kolaka Utara. Penelitian ini diharapkan dapat memberikan manfaat bagi guru, siswa, sekolah dan penelitian lainnya.

\section{Metode Penelitian}

Jenis penelitian adalah penelitian tindakan kelas (PTK). Penelitian ini dilaksanakan pada semester genap tahun pelajaran 2015/2016 di Kelas IV SDN 1 Mosiku Kabupaten Kolaka Utara dengan subjek penelitian adalah guru dan siswa Kelas IV SDN 21 Mosiku Kabupaten Kolaka Utara. Faktor yang diteliti adalah hasil belajar, siswa dan guru. Penelitian tindakan kelas ini dilaksanakan dalam dua siklus yang terdiri dari empat tahapan yaitu perencanaan, pelaksanaan tindakan, observasi dan evaluasi serta refleksi. Jenis data dalam penelitian ini adalah data kuantitatif berupa hasil belajar IPA siswa dan data kualitatif berupa hasil observasi aktivitas belajar siswa dan observasi aktivitas mengajar guru. Data dikumpulkan melalui observasi, yaitu melakukan observasi terhadap aktivitas mengajar guru dan aktivitas belajar siswa dengan model pembelajaran kooperatif tipe STAD dan evaluasi, yaitu melakukan tes hasil belajar kepada siswa setelah proses pembelajaran IPA melalui model pembelajaran kooperatif tipe STAD.

Analisis data dalam penelitian ini statistik deskriptif yang dimaksudkan untuk memberikan gambaran distribusi hasil belajar siswa

Ketuntasan individu siswa ditentukan berdasarkan nilai yang diperoleh pada setiap siklus. Siswa dikatakan belajar tuntas jika nilai yang diperoleh siswa adalah $\geq 65$ sesuai KKM yang ditetapkan sekolah.

Ketuntasan klasikal ditentukan berdasarkan persentase ketuntasan individu siswa pada setiap siklus pembelajaran dengan rumus sebagai berikut:

$$
\% \text { tuntas }=\frac{\sum f i}{n} \times 100 \%
$$

Dimana,

n: Jumlah siswa secara keseluruhan

$\sum f i$ : Jumlah siswa pada kategori ketuntasan belajar (Suparno, 2008:82)

Menentukan keberhasilan aktivitas mengajar guru dapat dilihat pada keterlaksanaan skenario pembelajaran. Untuk menentukan Keberhasilan Aktivitas Mengajar Guru (KAMG) dapat dilihat pada keterlaksanaan skenario pembelajaran. Persentase keterlaksanaan skenario pembelajaran dihitung berdasarkan jumlah skor perolehan guru dibagi jumlah skor maksimum dikalikan dengan seratus persen

Keberhasilan aktivitas belajar siswa (KABS) dihitung berdasarkan skor perolehan siswa dibagi jumlah skor maksimum dikalikan dengan seratus persen

Indikator keberhasilan dalam penelitian ini adalah 1) Hasil belajar siswa dikatakan berhasil apabila minimal $76 \%$ dari keseluruhan siswa memperoleh nilai minimal $65,2)$ Skenario pembelajaran dikatakan terlaksana dengan baik apabila minimal $80 \%$ skenario pembelajaran sesuai dengan penerapan model pembelajaran kooperatif tipe STAD telah terlaksana dengan baik

\section{Hasil Penelitian dan Pembahasan Hasil Belajar Siswa}

Berdasarkan hasil tes siklus I seperti terlihat pada tabel di atas, secara klasikal siswa yang memperoleh nilai $\geq 65$ sebanyak 17 siswa dari 28 siswa atau sebesar $60,7 \%$ sedangkan siswa yang memperoleh nilai $\leq 65$ sebanyak 11 siswa atau sebesar 39,3\% dengan nilai rata-rata 67,5. Berdasarkan hasil tes siklus II secara klasikal siswa yang memperoleh nilai $\geq 65$ 
sebanyak 25 siswa dari 28 siswa atau sebesar $89,3 \%$ dengan nilai rata-rata 76,8 .

Aktivitas guru dalam menerapkan model pembelajaran pada pertemuan pertama mencapai skor 26 atau $65 \%$ sedangkan pada pertemuan kedua mencapai skor 34 atau $85 \%$. Aktivitas guru dalam menerapkan model pembelajaran pada siklus II mencapai skor 36 atau $90 \%$.

Persentase hasil observasi aktivitas siswa pada pertemuan pertama adalah $60 \%$ mengalami peningkatan menjadi $75 \%$ pada pertemuan kedua. Persentase hasil observasi aktivitas siswa pada siklus II adalah $85 \%$.

\section{Pembahasan}

Berdasarkan hasil penelitian yang telah dilakukan menunjukkan bahwa dengan menerapkan model pembelajaran Cooperative Learning tipe STAD dalam pembelajaran memiliki dampak positif dalam meningkatkan hasil belajar IPA materi Energi dan Pengarunya Dalam Kehidupan pada siswa kelas III SDN 1 Mosiku. Hal ini dapat dilihat dari adanya peningkatan hasil belajar siswa pada setiap siklus. Rata-rata hasil tes siklus I adalah 67,5 dengan presentase ketuntasan $60,7 \%$. Namun nilai tersebut belum mencapai standar indikator yang telah ditentukan. Kemudian pada siklus II, rata-rata hasil tes siklus II adalah 76,8 dengan presentase ketuntasan $89,3 \%$. Hal tersebut menunjukkan bahwa hasil belajar siswa telah mencapai indikator yang telah ditetapkan yaitu $76 \%$ siswa telah memperoleh nilai $\geq 65$.

Berdasarkan hasil observasi pada siklus I, kegiatan belajar siswa belum terlaksana dengan baik dan masih terdapat kekurangan-kekurangan yang harus diperbaiki. Hal ini terlihat dari hasil observasi yang dilakukan yang menunjukkan masih ada halhal belum sepenuhnya terlaksana secara maksimal diantaranya: (1) tidak semua siswa antusias dalam motivasi yang dilakukan guru; (2) tidak semua siswa mendengarkan penjelasan guru tentang tujuan pembelajaran; (3) tidak semua siswa memperhatikan penjelasan materi dari guru; (4) tidak semua siswa mengerjakan LKS secara berkelompok atau berdiskusi; (5) masih ada beberapa siswa yang takut mempresentasekan hasil kerja kelompoknya; (6) belum semua siswa memperhatikan penjelasan guru tentang jawaban yang masih salah; (7) siswa masih banyak yang belum berani mengemukakan kesulitannya; (8) siswa kurang dilibatkan dalam membuat kesimpulan pelajaran.

Berdasarkan kekurangan-kekurangan tersebut, maka penelitian dilanjutkan pada siklus II. Pada siklus II siswa sudah dapat mengikuti pembelajaran dengan lebih baik, hal tersebut dapat dilihat dari meningkatnya hasil observasi siswa yaitu mencapai $85 \%$.

Analisis hasil observasi Aktivitas Siswa dalam pembelajaran menunjukkan bahwa pembelajaran dengan penerapan model pembelajaran Cooperative Learning tipe STAD memiliki dampak positif dalam meningkatkan kualitas Aktivitas Guru. Hal ini terlihat dari hasil observasi Aktivitas Guru pada setiap pertemuan. Pada siklus I, persentase kegiatan mengajar guru yaitu $65 \%$ pada pertemuan pertama dan meningkat menjadi $85 \%$ pada pertemuan kedua. Namun disadari masih terdapat kekurangan-kekurangn yang masih perlu diperbaiki, diantaranya: (1) guru menyampaikan materi pelajaran kurang sistematis dan agak cepat; (2) guru tidak membimbing semua siswa yang mengalami kesulitan; (3) guru tidak meminta siswa menanyakan materi pelajaran yang belum dimengerti; (4) guru tidak melibatkan siswa dalam membuat kesimpulan materi pelajaran.

Berdasarkan kekurangan yang ada pada siklus I maka pada siklus II peneliti lebih menitikberatkan perbaikan kekurangan tersebut agar pembelajaran berjalan lancar dan efektif sehingga pada siklus II persentase aktivitas belajar siswa mencapai $90 \%$.

\section{Simpulan}

1. Penerapan model pembelajaran kooperatif tipe STAD dapat meningkatkan hasil belajar siswa pada materi Energi dan Pengarunya Dalam Kehidupan di kelas III SDN 1 Mosiku Kabupaten Kolaka Utara. Hasil tes siklus I menunjukkan bahwa 17 dari 28 siswa kelas III telah mencapai nilai $\geq 65$ dengan persentase ketuntasan $60,7 \%$ dan rata-rata kelas 67,5. Pada siklus II persentase ketuntasan mencapai $89,3 \%$ dengan rata-rata kelas 76,8 . Hasil belajar siswa tersebut menunjukkan bahwa indikator kinerja telah tercapai yaitu minimal $76 \%$ siswa memperoleh nilai $\geq 65$. 
2. Persentase aktivitas siswa dalam mengikuti pembelajaran kooperatif tipe STAD selalu meningkat, ini dapat dilihat dari pencapaian indikator. Pada siklus I aktivitas siswa mencapai $60 \%$ pertemuan pertama dan $75 \%$ pada pertemuan kedua. Pada siklus II meningkat menjadi $85 \%$. Hal tersebut menunjukkan bahwa siswa telah dapat mengikuti pembelajaran dengan menggunakan model pembelajaran kooperatif tipe STAD dengan baik.

3. Persentase aktivitas guru dalam pembelajaran kooperatif tipe STAD selalu meningkat, ini dapat dilihat dari pencapaian indikator. Pada siklus I aktivitas guru mencapai $65 \%$ pertemuan pertama dan $85 \%$ pada pertemuan kedua. Pada siklus II meningkat menjadi $90 \%$. Hal tersebut menunjukkan bahwa kegiatan mengajar guru dengan menggunakan model pembelajaran kooperatif tipe STAD telah dilaksanakan dengan baik dan mencapai indikator kinerja.

\section{Daftar Pustaka}

Kolewora, 2010. Meningkatkan Kemampuan Siswa pada Materi Pokok Alat Indra Manusia Mata Pelajaran IPA Melalui Penerapan Model Pembelajaran Kooperatif Tipe STAD Pada Siswa Kelas IV SDN 1 Kabangka Kabupaten Muna. Skripsi, Kendari: FKIP Unhalu.

Slavin E. R., 2005. Cooperative Learning. Boston: Allyn and Bacon.

Suparno Paul. 2008. Riset Tindakan untuk Pendidik. Jakarta: Grasindo.sedangkan $12 \%$ atau 3 dari 24 siswa dinyatakan tidak tuntas dengan nilai rata-rata mencapai 80 . 